Jurnal Ilmu dan Teknologi Kesehatan

Vol 8, No 1, September 2020,

ISSN: 2338-9095 (Print)

ISSN: 2338-9109 (online)

\title{
Improvement of Family Care Ability for Elderly with Depression through Psychoeducation Intervention Program
}

\author{
Ni Made Riasmini \\ Poltekkes Kemenkes Jakarta III, Indonesia \\ Email: maderiasmini@yahoo.co.id
}

\author{
Article history \\ Posted, Aug 5th, 2020 \\ Reviewed, Sept 10th, 2020 \\ Received, Sept 27th, 2020
}

\begin{abstract}
The increase in the incidence of depression in the elderly can affect the elderly and their families' quality of life. Depression in the elderly is mostly caused by a lack of knowledge, attitudes, and family behavior caring for the elderly. It has an impact on the increasing cases of older people with depression in the community. To prevent increasing depression cases, it is necessary to empower family potential and social support. This study aims to obtain a description of the Psychoeducation Intervention Program (PIP) on families' ability to care for older people with depression in the community. The research method used is a Quasiexperiment with control group design. The sample is families who have elderly with depression by screening using the Geriatric Depression Scale Short Form (GDS-SF). The number of samples was 68 for the intervention group and 68 for the control group-statistical test using dependent t-test, independent t-test, and Mancova test. The results showed an increase in knowledge, attitudes, and family behavior in caring for the elderly before and after PIP. There were differences in the family's ability to care for the depressed elderly between the intervention and control groups. The resulting psycho-educational intervention program can serve as a basis for policymakers and health service managers to carry out various interventions related to family empowerment.
\end{abstract}

Keywords: ability to care; depression in the elderly; psychoeducation intervention program

\begin{abstract}
ABSTRAK
Peningkatan kejadian depresi pada lanjut usia (lansia) dapat berpengaruh terhadap kualitas hidup lansia dan keluarganya. Depresi pada lansia banyak disebabkan oleh kurangnya pengetahuan, sikap dan perilaku keluarga dalam merawat lansia sehingga berdampak pada semakin tingginya kasus lansia dengan depresi di masyarakat. Untuk mencegah terjadinya peningkatan kasus depresi, diperlukan peningkatan kemampuan melalui pemberdayaan potensi keluarga serta dukungan sosial. Penelitian ini bertujuan memperoleh gambaran tentang efektifitas Program Intervensi Psikoedukasi (PIP) terhadap kemampuan keluarga merawat lansia dengan depresi di masyarakat. Metode penelitian menggunakan Quasi experiment with control group design. Sampel adalah keluarga yang mempunyai lansia dengan depresi dengan skrining menggunakan Geriatric Depression Scale Short Form (GDS-SF). Jumlah sampel sebanyak 68 untuk kelompok intervensi dan 68 untuk kelompok kontrol. Uji statistik
\end{abstract}


menggunakan dependent t-test, independent t-test dan uji Mancova. Hasil penelitian menunjukkan terjadi peningkatan pengetahuan, sikap dan perilaku keluarga dalam merawat lansia sebelum dan sesudah PIP. Ada perbedaan kemampuan keluarga dalam merawat lansia depresi antar kelompok intervensi dan kelompok kontrol. Program intervensi psikoedukasi yang dihasilkan dapat dijadikan sebagai landasan bagi pemangku kebijakan dan pengelola pelayanan kesehatan dalam rangka melaksanakan berbagai intervensi yang berkaitan dengan pemberdayaan keluarga.

Kata Kunci: kemampuan merawat; depresi pada lansia; program intervensi psikoedukasi

\section{INTRODUCTION}

A depressive disorder that is often found in the elderly is a psychososiogeriatric problem and needs special attention. Depression in the elderly is sometimes not detected early and can not be adequately treated because the symptoms that appear are often considered part of the normal aging process. The data on the incidence of depression in the world and Indonesia varies widely. In North America, the prevalence of older people experiencing depressive symptoms in the community is around $8-27 \%$. The incidence of depression increases in the elderly treated in hospitals or health institutions (Gonzales, 2012). Waren and Taylor (2014) revealed that the rate of depression in the elderly in the community is around 5\% and is treated in health institutions around 8-16\%. Indonesia also has an increased incidence of depression in the elderly. The results of Wulandari's (2011) study show that the proportion of depression in the elderly in the community is more significant $(60 \%)$ than the proportion of depression in the elderly in nursing homes (38.5\%). Based on Riskesdas 2018, it was found that the incidence of depression was $6.1 \%$, in DKI Jakarta, it was 5.9\%, and Bali Province was $5.1 \%$. The incidence of depression in the elderly (65-74 years) was $8 \%$, more in older women $(7.4 \%)$ than men, and more in elderly living in urban areas $(6.5 \%)$ than in rural areas.

Depression in the elderly is also caused by a lack of knowledge, attitudes, and family caring behavior for the elderly. It impacts the increasing number of older people with depression, especially with a shift in culture and community life patterns. Depression experienced by the elderly can affect the quality of life and their families. Role tensions are stressors experienced by families such as disturbances in relationships with other people, disruption in carrying out tasks due to time spent caring for. Families who experience role tension will experience a higher level of burden and experience physical and mental health problems and affect the quality of the 
relationship between the family and the elderly (Gupto, Pillai \& Levy, 2012)

Overcoming the increasing incidence of depression in the elderly requires empowering family potential and social support. Family is the primary source of support for the elderly in society. The effectiveness of family support is a crucial component of the welfare of the elderly. The results of Kaufman and Kosberg's (2010) study found that informal social support from family and friends can reduce stress, increase problem-solving skills, increase healthy behavior, increase welfare, reduce stress and family burdens (caregiver). Social support from the family is beneficial for the health and well-being of the elderly and can protect the elderly from dangerous situations and stressful life events (Khan \& Khan, 2011). The results of research by Saju, Kusuma, and Lasri (2018) found that there was a relationship between family support and the depression level in the elderly of $52.2 \%$.

The Psychoeducation Intervention Program (PIP) is a form of family empowerment, a strategy for providing information to families about illnesses and how to treat them, training in coping skills, controlling tension and stress, and interpersonal and communication skills. The research results by Chien, Leung, and Chu (2012) illustrate that psycho-educational interventions have a positive effect in reducing the recurrence of the client's disease, increasing understanding and coping in overcoming problems, and increasing client-oriented care in the community. Health education and family support can prepare families to provide better care to clients. The results of Banon's (2011) study found a $27.7 \%$ reduction in depression in the group that received reminiscence therapy and family psychoeducation. Also supported by the research results by Putri, Utami, and Taruma (2019), which found that storytelling therapy affected reducing depression levels in the elderly. However, there is no research on the effectiveness of the Psychoeducation Intervention Program (PIP) on families' ability to care for older people with depression in the community. Through psychoeducation intervention, it is hoped that it can improve the family's ability to care for the elderly in the community. It is hoped that the psychoeducation intervention program can empower families by increasing the ability to care for and solve problems in the family. 


\section{METHOD}

This study used a quasi-experimental prepost test design with a control group design. This research was conducted in DKI Jakarta and Bali Province. The population is families who have older people with depression. In comparison, the sample of the study is a family/caregiver who cares for older people with depression at home with the following criteria: adults to preelderly (21-59 years), living with the elderly in one house, responsible for caring for the elderly (as the primary caregiver).

The sampling strategy uses a multistage cluster method. The sample size was 136 people (68 intervention group and 68 control group). This research was conducted in DKI Jakarta and Bali Province, so that the number of samples was divided proportionally according to the number of older people into three groups, namely: Group I: PIP (Training + Family Meeting + Home visit) as many as 46 (DKI Jakarta $=27$, Prov. Bali $=19$ ), Group II: PIP (Training + Family meeting) as many as 46 (DKI Jakarta = 27, Prov. Bali $=19$ ), and Group III: Without treatment/control as many as 46 (DKI Jakarta $=27$, Prov Bali $=$ 19). All participants have explained the research and have given consent to become participants by signing informed consent.

Psychoeducation intervention program is a form of intervention applied to families who care for the elderly. Activities undertaken are: 1) Providing training to caregivers about depression and how to care for older people with depression as well as how to detect and prevent cases of depression; 2) Conducting family gatherings, where families are taught how to manage stress, sleep hygiene, how to solve problems, interpersonal skills and communication. Meetings are held four times (2 weeks); 3) Conduct supervision through home visits to assess the family's ability to care for depressed elderly. Home visits were carried out twice, named after two family gatherings and at the end of family gatherings. Researchers involved health center nurses in conducting training, family meetings, and supervision.

The instrument used to measure the health status of the elderly and caregivers, is a modification of the Short Form Health Survey (SF-12) consisting of 12 items using a Likert scale of 1-5. Geriatric Depression Scale-Short Form (GDS-SF) is also used to assess mental health status. Social support was measured using a modified MOS social support survey questionnaire, consisting of 20 items with a Likert scale of 0-4. An instrument to measure the family's ability to care for the elderly (knowledge, attitudes, and skills) developed by the researcher. The family knowledge instrument consists of 25 
items with correct (1) and false (0) answers. Attitude consists of 20 items with a Likert scale of $0-3$, and skills consist of 20 items with answers done (1) and not done (0).

Data analysis used univariate, bivariate, and multivariate analysis. Statistical test using dependent t-test, independent t-test, and the Mancova test.

\section{RESULTS AND DISCUSSION}

The analysis of the characteristics of the elderly showed that the mean age in the intervention groups I, II, and control was almost the same, around 69 years. The majority were female, more than half of the married status in the intervention group was widowed / widower, while the control group was married; most primary school education in the intervention group II and control. While in the intervention group I most had junior high school education, the level of depression experienced by the elderly in the three groups, namely mild depression, was almost the same as a mean value of 34 .

Family characteristics showed that the three groups' mean age was almost the same, namely around 43 years, the youngest 18 years old and the oldest 59 years old. The majority are female, and married status is married. More than half are educated $<$ high school, majority income <UMR. More than half the type of family in the intervention group I and control is a large family. While the intervention group II: nuclear family, family relations with the elderly are more as parents, and the social support for the three groups was almost the same with a mean score of about 23. 
Table 1. Analysis of the care ability before and after the psychoeducation intervention in the intervention group I, II, and the control group

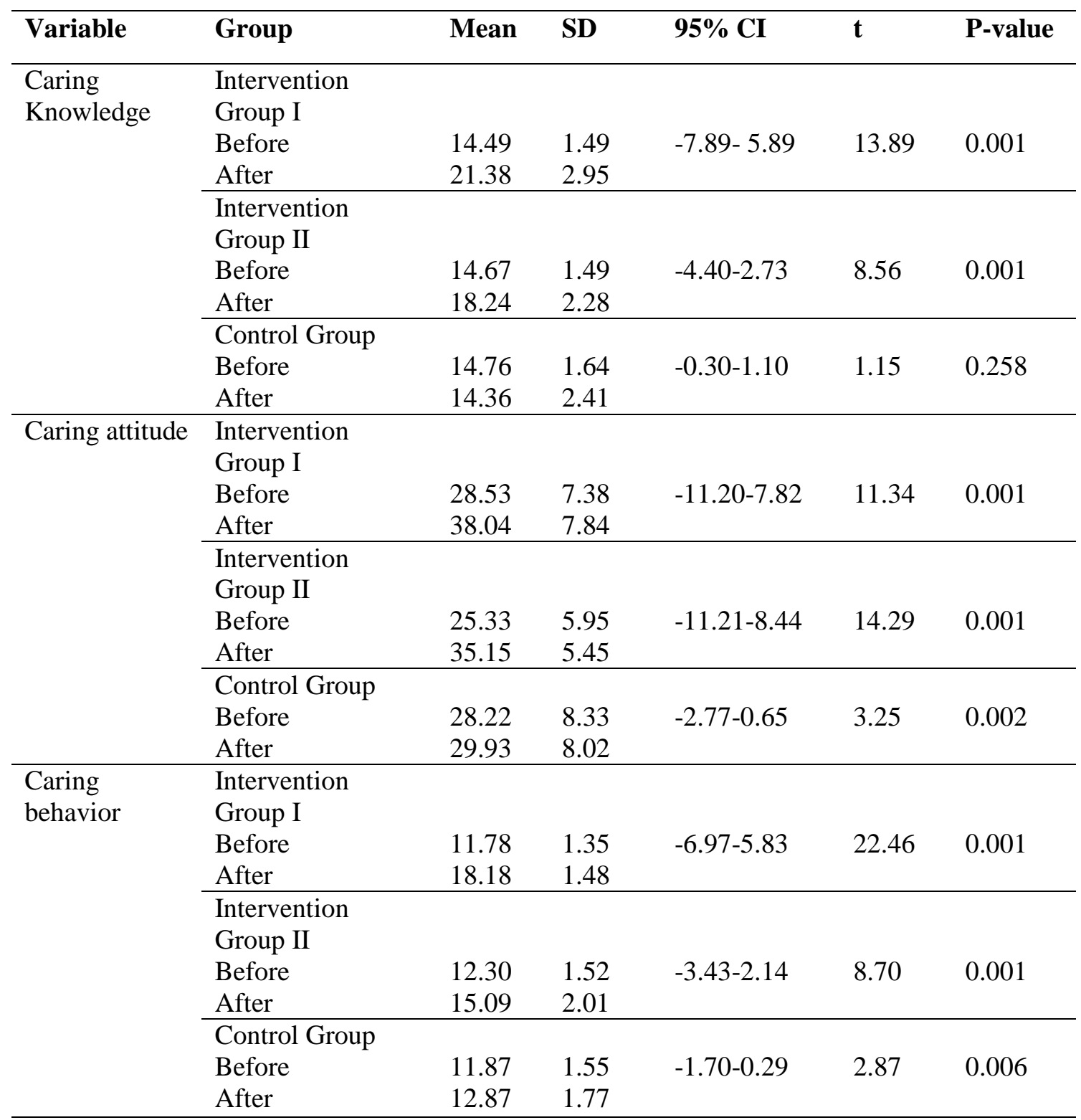

The analysis results showed significant differences in caring for the intervention groups I and II before and after the psychoeducation intervention $(\mathrm{p}$-value $=$ 0.001), with a more significant difference in mean values in the intervention group I compared to the intervention group II. Whereas in the control group, there was no significant difference in family knowledge in caring for the elderly with depression (pvalue $=0.258)$. The research results on caring attitudes found significant differences in the attitude of care in the three groups before and after the psychoeducation intervention ( $\mathrm{p}$-value $<0.05$ ), with the largest difference in mean values in the intervention group II. Likewise, with caring behavior, it was 
found that there were significant differences in caring behavior in the three groups before and after the psychoeducation intervention (p-value $<0.05)$, with the largest difference in mean values in the intervention group I.

Table 2. Analysis of the family's ability to care for depressed elderly after the inter-group psychoeducation intervention

\begin{tabular}{llllllll}
\hline Variable & Group & N & Mean & SD & 95\% CI & F & $\begin{array}{l}\text { P- } \\
\text { value }\end{array}$ \\
\hline Caring & Intervention I & 45 & 21.38 & 2.95 & $20.49-22.26$ & 84.81 & 0.001 \\
Knowledge & Intervention II & 46 & 18.24 & 2.28 & $17.56-18.92$ & & \\
& Control & 45 & 14.36 & 2.41 & $13.63-15.08$ & & \\
\hline Caring & Intervention I & 45 & 38.04 & 7.84 & $35.69-40.40$ & 14.73 & 0.001 \\
attitude & Intervention II & 46 & 35.15 & 5.45 & $33.53-36.77$ & & \\
& Control & 45 & 29.93 & 8.02 & $27.52-32.34$ & & \\
\hline Caring & Intervention I & 45 & 18.18 & 1.48 & $17.73-18.62$ & 102.52 & 0.001 \\
behavior & Intervention II & 46 & 15.09 & 2.01 & $14.49-15.68$ & & \\
& Control & 45 & 12.87 & 1.77 & $12.34-13.40$ & & \\
\hline
\end{tabular}

The analysis results showed that there were differences in knowledge, attitudes, and care behaviors between the intervention groups I, II, and the control group after the psychoeducation intervention $(\mathrm{p}$-value $=$ 0.001). The results also showed significant differences in knowledge, attitudes, and behavior of care in the intervention groups I and II before and after the psychoeducation intervention.

Psychoeducation can improve family knowledge about depression, wrong perceptions regarding causes of depression, changes in elderly that occur due to depression, and the impact of depression on the health of the elderly and an increase in the burden of caring for the family. The family's inability to take a stand in the care of the elderly is caused by ambivalence. Busy life patterns and work demands but a culture of respect for the elderly make it very difficult for many people to make decisions (Chang \& Sceneider, 2010). Psychoeducation can help families make decisions well and proportionately to provide care for the elderly while maintaining their primary role and function as caregivers in the family.

The results of this study are in line with research conducted by Wiyati, Wahyuningsih, and Widyati (2010) on clients with social isolation where psychoeducation can influence the didactic ability of the family, including the family's ability to recognize depression problems in 
the elderly, be able to make appropriate interventions and be able to perform selfmanagement better so that it can reduce relationship problems between the elderly and their families.

It is also supported by the research results of Timmerby, Austin, Ussing, Bech, and Csillag (2016) that family psychoeducation is a strategy to overcome problems and provide support to family members who experience depression. The new knowledge and strategies the family has not only helps the family recognize the symptoms of depression but also help them provide better support to prevent relapse and maintain recovery. Likewise, the research results of Indriani, Hayati, and Wihastuti
(2020) illustrate that psychoeducation can improve cognitive abilities or family knowledge. Family supports so that families understand the symptoms of elderly depression, help families recognize elderly behavior deviations to reduce the scale of depression in the elderly.

The research results by George, Sharma, and Nair (2015) showed a significant increase in caregiver knowledge and attitudes in the intervention group compared to the control group $(\mathrm{p}=0.001)$. Psychoeducation has been shown to increase knowledge and attitudes among caregivers and reduce the burden on families.

Table 3. The effect of family characteristics on the family's ability to care for depressed elderly

\begin{tabular}{llllll}
\hline Variable & B & Std.Error & T & P-value & 95\% CI \\
\hline $\begin{array}{l}\text { Caring ability } \\
\begin{array}{l}\text { Family relationship } \\
\text { with elderly }\end{array}\end{array}$ & 1.601 & 0.770 & 2.080 & 0.040 & $0.078-3.125$ \\
\hline
\end{tabular}

Based on the results of the multivariate test, it was found that the independent variable that affects the ability of the family caring for the elderly, especially the behavior of caring, is the relationship between family and the elderly (as parents) with a p-value of 0.040 , the strength of the relationship is $54.2 \%$.

When viewed from the family relationship, it appears that caring for the elderly with depression correlates with the relationship between family and the elderly (parents). Culturally, the responsibility to care for parents is the responsibility of the child. Generally, married girls have full responsibility in caring for their parents (Arsana, Suci, \& Dharmika, 2001). The child or daughter-in-law is the primary caregiver in caring for the elderly; two- 
thirds of the caregiver is a woman's family or daughter-in-law (WHO, 2003).

When viewed from kinship, it appears that most depressed elderly in Bali live in extended families, while in DKI Jakarta, they live in nuclear families. In general, families in Bali still live with an extended family. All boys have the same responsibilities to their parents: economic, cult, social, and production. The opportunity to stay together in a large family is also supported by the geographical conditions of the relatively close family's workplace so that the family can still care for the elderly. Supported by the research results of Orfila et al. (2018) stated that previous good relationships and positive perceptions such as loving, respecting the elderly with all their limitations, providing support are positive aspects of family care for the elderly which will increase their interaction and role in caring for the elderly.

\section{CONCLUSION}

Psychoeducation interventions have been proven to effectively increase knowledge, attitudes, and behavior of families as caregivers in caring for the elderly. Therefore, it is hoped that this psychoeducation can be used as one of the family empowerment interventions used in community nursing service settings. Public health center nurses' ability also needs to be improved to assist families in caring for older people with depression at home. It is also necessary to design health promotion interventions for the elderly to overcome depression through sharing, relaxation exercises, and developing hobbies.

\section{ACKNOWLEDGMENT}

The researcher would like to express his deepest gratitude to the Health Polytechnic of the Ministry of Health, Jakarta III, who has helped sponsor this research.

\section{REFERENCE}

Arsana G.K.G., Suci Kt., Suci Nym., \& Dharmika I.B. 2001. Dampak Modernisasi Terhadap Hubungan Kekerabatan di Bali. Jakarta: Departemen Pendidikan dan Kebudayaan.R.I.

Banon, E. 2011. Pengaruh Terapi Reminiscence dan Psikoedukasi Keluarga terhadap Kondisi Depresi dan Kualitas Hidup Lansia di Katulampa Bogor. Tesis. Jakarta: Fakultas Ilmu Keperawatan UI.

Chien, W.T., Leung, S.F.,\& Chu, C.S.K., 2012. A nurse-led, Needs-Based Psycho-Education Intervention for Chinese Patients with First-onset Mental Illness. Contemporary Nurse, 40 (2): 194-209

Dewi, dkk. 2007. Depresi pada lansia di RSCM.http://www.kalbe.co.id/files/c dk/ files/cdk_156_Depresi.pdf. 
George, L.S., Sharma, \& Nair, S. 2015. Effect of psychoeducation on Knowledge, Attitude, and Burden among caregivers of persons with Bipolar Disorder-Randomized Controlled Trial. International Journal of Advanced Research, 3(7):199-208.

Gonzales, L.A.M., et al. 2010. The experience of family caregivers of older people with depression. Rev Esc Enferm USP, 44(1):32-8.

Gupta, R., Pillai, V.K., \& Levy, E.F. 2012. Relationship Quality and Elder Caregiver Burden. Journal of Social Intervention: Theory and Practice, 21(2): 39-62.

Indriani, C., Hayati, Y.S., \& Wihastuti, T.A. 2020. Family Psychoeducation in Reducing the Occurrence of Depression in Elderly: A Systematic Review. International Journal of Science and Society, 2(3).

Kaufman, A.V., \& Kosberg, J.I. 2010. Social Support, Caregiver Burden \& Life Satisfaction in a Sample of Rural African American and White Caregiver of Older Persons with Dementia. Journal of Gerontological Social Work, 53: 251-269.

Kemenkes, R.I. 2018. Laporan Nasional Riskesdas 2018. Jakarta: Badan Penelitian dan Pengembangan Kesehatan.

Khan, M.T., Sulaiman, S.A.S., Hassali, M.A., Anwar, M., Wasif, G., \& Khan A.H. 2009. Community knowledge, attitudes, and beliefs toward depression in the state of Penang, Malaysia. Community Mental Health Journal, 46:87-92

Lemeshow, S., Holmer, D.W., Klar, J., \& Lwanga, S.K. 2002. Besar Sampel dalam Penelitian Kesehatan. (Pramono, D., \& Kusnanto, H., Penerjemah). Yogyakarta : Gadjah Mada University Press.

Orfila et al. 2018. Family Caregiver Mistreatment of the Elderly: Prevalence of Risk and Associated Factors. BMC Public Health, 18:167 DOI $\quad 10.1186 / \mathrm{s} 12889-018-$ 5067-8.

Saju, K.S., Kusuma, F.H.D., \& Lasri. 2018. Hubungan Dukungan Keluarga dengan Tingkat Depresi Lansia Usia 60-74 Tahun yang Mengikuti Kegiatan Karang Wredha. Nursing News, 3(1).

Timmerby, N., Austin, S.F., Ussing, K., Bech, P., \& Csillag, C. 2016. Family psychoeducation for major depressive disorder-study protocol for a randomized controlled trial. Trials, 2016; 17(1): 427.

Warren, D., \& Taylor, M.D. 2014. Depression in the Elderly. The new England journal of medicine, 371:1228-36.

WHO. 2003. Conquering depression, WHO regional office for South-East Asia, New Delhi.

Widnya. 2008. Bunuh diri di Bali perspektif budaya dan lingkungan hidup. Journal Institut Hindu Dharma Negeri.

Wulandari, A.F.S. 2011. Kejadian dan Tingkat Depresi pada Lanjut Usia : Studi Perbandingan di Panti Wreda dan Komunitas. Karya Tulis Ilmiah. Semarang: Program Pendidikan Sarjana Kedokteran Fakultas Kedokteran Diponegoro. 